\title{
New York University School of Law
}

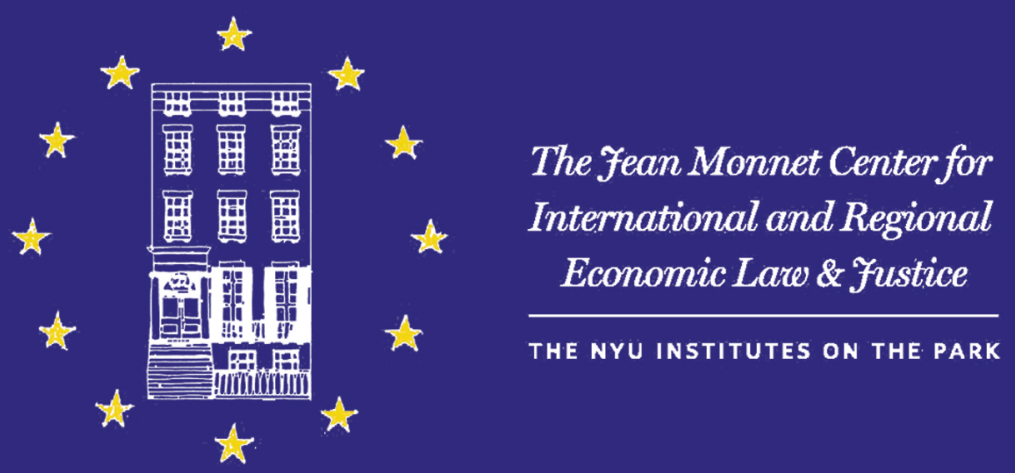

\section{Jean Monnet Working Paper Series}

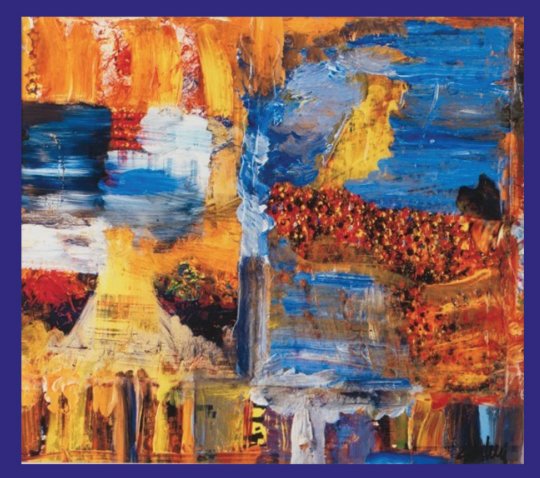

JMWP 08/15

Jure Vidmar

The Use of Force and Defences in the Law of State Responsibility 
Cover: Billy The Kid, 2000, Steven Lewis 


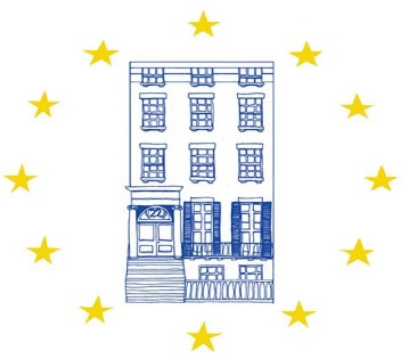

The Fean Monnet Center for International and Regional Economic Law \& Fustice

THE NYU INSTITUTES ON THE PARK

\section{THE J EAN MONNET PROGRAM}

J.H.H. Weiler, Director

Gráinne de Burca, Director

J ean Monnet Working Paper 08/ 15

J ure Vidmar

The Use of Force and Defences in the Law of State Responsibility

NYU School of Law • New York, NY 10011

The J ean Monnet Working Paper Series can be found at www.J eanMonnetProgram.org 
All rights reserved.

No part of this paper may be reproduced in any form without permission of the author.

ISSN 2161-0320 (online)

Copy Editor: Danielle Leeds Kim

(C) Jure Vidmar 2015

New York University School of Law

New York, NY 10011

USA

Publications in the Series should be cited as: 


\title{
THE USE OF FoRCE AND DEFENCES IN THE LAW OF STATE RESPONSIBILITY
}

\author{
By J ure Vidmar
}

\begin{abstract}
Justifications and excuses have developed in various legal systems as defences for wrongful acts. In international law, defences appear in the ILC Articles on State Responsibility, but they conflate justifications and excuses. This article argues in favour of a systematic separation of the two types of defences in international law and applies the typology to the use of force framework. Justifications are legally authorised exceptions to the primary norm. If a prima facie wrongful act can be justified, it is not wrongful. Excuses are defences for acts that are deliberately wrongful but, in the particular circumstances, may be seen as the choice of the lesser evil. The article demonstrates that self-defence under Article 51 UN Charter, Security Council's authorisation, and intervention by invitation belong to justifications of the use of force. Conversely, humanitarian intervention and perhaps even anticipatory self-defence could be seen as excuses under the defence of necessity. Excuses do not preclude wrongfulness but only mitigate against responsibility for a wrongful act. The use of force that is excused but not justified, therefore, cannot be taken as state practice relevant for an emergence of a customary justification. The excuses/justifications typology preserves the strength of the prohibition of the use of force but acknowledges certain mitigating circumstances where force is used illegally. The article shows that excuses of illegal use of force have been accepted in practice of states and UN organs.
\end{abstract}




\section{Introduction}

In a paper presented at the 1956 Meeting of the Aristotelian Society in London, JL Austin outlined two different approaches to defending a wrongful act: In the one defence ... we accept responsibility but deny that it was bad; in the other, we admit that it was bad but don't accept full, or even any, responsibility.'1 The first defence is a justification, the second one is an excuse. Explaining this difference further, Kent Greenawalt argues that the central distinction between justification and excuse is between warranted action and unwarranted action for which the actor is not to blame.'2 An act can be wrongful prima facie, but the applicable law can provide for a justification which precludes wrongfulness. Excuses are different. They cannot preclude wrongfulness of an act, but under some circumstances the wrongdoer will be excused from responsibility for the wrongdoing. The act itself will, however, remain wrongful.

A conceptual distinction between justifications and excuses has developed in municipal legal systems, in both criminal and civil matters. 3 In international law, the concept of defences is found in the rules on state responsibility. The International Law Commission (ILC) Articles on Responsibility of States for Internationally Wrongful Acts (ARSIWA, the ILC Articles on State Responsibility) include the chapter on circumstances that preclude wrongfulness, but these rules do not draw a systematic difference between justifications and excuses.4 As Vaughan Lowe illustrates, a legal system may wish to provide a defence for emergency drivers who breach the speed limit on the way to hospital.5 There are two ways of achieving this goal. One way is to give them an explicit authorisation to breach the speed limit. The other one, however, does not authorise speeding, but rather ensures that emergency drivers are not prosecuted upon such a breach of traffic rules. The first (justification) relaxes the norm itself and

1 J.L. Austin, 'A Plea for Excuses: The Presidential Address', 57 Proceedings of the Aristotelian Society (1956-1957), 1, at 2.

${ }^{2}$ K. Greenwalt, The Perplexing Borders of J ustification and Excuse', 84 Col LR (1984) 1897, at 1927.

3 While analogies are often drawn to domestic criminal law, a distinction between justifications and excuses also exists in contracts and torts. Analogies with the law of state responsibility are thus plausible, as even in municipal legal systems defences are not only a matter of criminal responsibility. For an overview of the distinction justifications/ excuses with regard to criminal and civil liability, see A. Botterell, 'A Primer on the Distinction between J ustification and Excuse', 4 Philosophy Compass (2009) 172.

4 See V. Lowe, 'Precluding Wrongfulness or Responsibility: A Plea for Excuses', 10 EJ IL (1999) 405; I. Johnstone, The Plea of "Necessity" in International Legal Discourse: Humanitarian Intervention and Counter-Terrorism', 43 Col J TL (2004-2005), at 337.

${ }^{5}$ Lowe, supra note 4 , at 410 . 
may well result in wider disobeying of the speed limit than the second, which merely provides for a carefully weighed excuse of culpability where the norm was doubtlessly breached.6 In other words, it is better if the general primary norm is strong and 'catches' more violators whose excuses are then considered on a case-by-case basis. ${ }^{7} \mathrm{~A}$ systematic separation of justifications and excuses, therefore, does not come with the peril that the accepted excuses could expand on justifications and thus undermine the strength of the primary norm itself. But the lack of a centralised compulsory jurisdiction to consider excuses on an individual basis certainly remains a potent problem in international law. Is it conceptually possible to accommodate excuses within the system of international law? 8

This article applies the concept of defences to the rules governing the use of force. Article 2(4) of the UN Charter contains the general prohibition, ${ }^{9}$ while Articles 42 and 51 authorise the exceptions: Security Council authorisation ${ }^{10}$ and self-defence, ${ }^{11}$ respectively. In other words, Article 2(4) determines that the use of force is prima facie wrongful under international law, yet using force pursuant to Articles 42 and 51 is legally warranted. These are justifications that preclude international wrongfulness. As a consequence, the use of force under such circumstances does not constitute an

\footnotetext{
6 ibid.

7 The distinction between the primary and secondary rules adopted in this article relates to the distinction established by the International Law Commission: The articles do not attempt to define the content of the international obligations, the breach of which gives rise to responsibility. This is the function of the primary rules, whose codification would involve restating most of substantive customary and conventional international law.' ARSIWA, General Commentary, para 1. The difference between primary norms and the rules of state responsibility was framed by the ICJ in the Hungary/Slovakia case: 'A determination of whether a convention is or is not in force, and whether it has or has not been properly suspended or denounced, is to be made pursuant to the law of treaties [primary rules]. On the other hand, an evaluation of the extent to which the suspension or denunciation of a convention, seen as incompatible with the law of treaties, involves the responsibility of the State which proceeded to it, is to be made under the law of state responsibility [secondary rules].' Gabcikovo-Nagymaros Project (Hungary/Slovakia), Judgment, ICJ Rep 1997, para 47. This conceptualisation of a distinction between primary and secondary rules in international law - at least for the purposes of the law of state responsibility - is different from the one developed by HLA Hart, and thus should not be conflated for the primary/ secondary rules dichotomy commonly known in general jurisprudence. For more see H.L.A. Hart, The Concept of Law (3rd edn OUP, 2012), at 79 - 99.

8 See R. Sloane, 'On the Use and Abuse of Necessity in the Law of State Responsibility', 106 AJ IL (2012) 447.

9 See A. Roberts, 'Legality vs. Legitimacy: Can Uses of Force Be Illegal But J ustified?' in P. Alston and E. Macdonald (eds), Human Rights, Intervention, and the Use of Force (OUP, 2008), at 179. Sloane, supra note 8.
}

${ }^{10}$ Art. 42 UN Charter.

${ }^{11}$ Art. 51 UN Charter. 
internationally wrongful act. When force is not used pursuant to these legally warranted exceptions, can it be excused rather than justified?

The objective of this article is not to design, redesign or reappraise the rules on the use of force. It rather adopts the so-called orthodox reading of the UN Charter 12 and conceptualises the exceptions to the prohibition of the use of force as defences under the law of state responsibility. The article takes a stance against the present conflation of justifications and excuses in international law. It demonstrates that excuses of illegal use of force have been accepted through practice of states and UN organs. Such practice should not be seen as being indicative of an extra-Charter customary exceptions to the prohibition of the use of force. Rather, under some circumstances defences can mitigate against responsibility, whereas force was still used illegally.

\section{Defences and the Law of State Responsibility}

The ILC Articles on State Responsibility contain a chapter entitled 'Circumstances Precluding International Wrongfulness' which enumerate defences. 13 In 1999, Lowe published his 'plea for excuses' which presents the argument that justifications and excuses in the ILC Articles are conflated.14 The framework of the ILC Articles thus provides for no systematic differentiation between the two types of defences. This is problematic not only from the perspective of the theory of defences, but also in terms of division between primary norms and the rules of state responsibility. This section makes an argument in favour of keeping justifications and excuses separate, and draws a difference between precluding wrongfulness and mitigating against responsibility for wrongfulness in the use of force context.

A. Precluding wrongfulness or mitigating against responsibility for wrongfulness According to Lowe, the ILC's work on the circumstances precluding wrongfulness, inter alia, assumes that, save for jus cogens, the injured state may release the wrongdoing

\footnotetext{
12 See, e.g., Sloane, supra note 8, at 448, who defines the 'orthodox reading of the UN Charter' as the one which allows for force being used only under these two carefully limited exceptions.

${ }^{13}$ Articles 20-27 ARSIWA (Part I, Chapter V).

14 Lowe, supra note 4.
} 
state from any wrongfulness. ${ }^{15}$ This appears to be conceptually wrong. All the injured state can do, under some circumstances, is release the wrongdoing state from responsibility for wrongfulness, but it does not have the power to declare that the act was not wrongful in the first place.16 Namely, rules of general international law do not operate merely on a bilateral basis, in this case between the wrongdoing and the injured state. If there was an internationally wrongful act, it cannot be decided on a bilateral basis that there, in fact, was no internationally wrongful act. What can be done is that such an act is excused and responsibility precluded. This happens on the level of the secondary rules of state responsibility, it cannot affect the content of the primary norm.

The Commentary on the ILC Articles on State Responsibility readily admits that the chapter on precluding wrongfulness conflates justifications and excuses.17 According to Special Rapporteur Crawford, the Articles leave it unclear whether they take the approach of exculpation or excuse.18 He further notes that in some circumstances it may be that responsibility is precluded rather than wrongfulness, '[b]ut this is not equally the case for each of the six circumstances in Chapter V.'19 In the case of necessity (Article 25), it is indeed responsibility that is precluded, not wrongfulness.20 Furthermore, distress (Article 24) could in many circumstances also fall under defences where the act remained wrongful but responsibility for wrongfulness was precluded. 21

Article 24(1) of the ILC Articles reads: The wrongfulness of an act of a State not in conformity with an international obligation of that State is precluded if the author of the act in question has no other reasonable way, in a situation of distress, of saving the author's life or the lives of other persons entrusted to the author's care.'22 The Commentary specifies that in practice 'cases of distress have mostly involved aircraft or ships entering State territory under stress of weather or following mechanical

\footnotetext{
15 ibid. at 406

16 ibid.

${ }^{17}$ Lowe, supra note 4 , at 406 .

${ }^{18} \mathrm{~J}$. Crawford, 'Revising the Draft Articles on State Responsibility', 10 EJ IL (1999) 435, at 443.

19 ibid.

20 ibid. at 444.

${ }^{21}$ Lowe, supra note 4 , at 408 . This is not to say that every defence in the law of state responsibility can be categorised as either justification or excuse. As in domestic settings, a defence can sometimes be both (Greenwalt, supra note 2, at 1897). Distress under the law of state responsibility could also fall within either defence, depending on the circumstances.

22 Art. 24(1) ARSIWA.
} 
or navigational failure.'23 On the level of primary norms, no general rule allows, e.g., a military aircraft of state A to enter the airspace of state B without consent due to bad weather, mechanical or navigational failure. But when this happens, state A can invoke these circumstances as an excuse. The reactions of the injured states invoked in the Commentary to Article 24 prove that such excuses are generally accepted and the responsible states released from responsibility.

Conversely, Article 21, ILC Articles, invokes self-defence. The Commentary to Article 21 refers to Article 51, UN Charter.24 According to Crawford, self-defence is an inherent right and is thus different from, e.g., necessity, where wrongful conduct is deliberate 'in order to preserve the overriding interest of the state concerned.'25 But why is self-defence then included in the secondary rules of state responsibility at all? Conceptually, should the law of state responsibility even be concerned with justifications or only with excuses?

As Robert Sloane rightly identifies, conflating inherent rights and excusable wrongs in the law of state responsibility means a conflation of primary and secondary rules, not only a conflation of two kinds of defences. ${ }^{26}$ This is indeed implied already in the title of the chapter on precluding wrongfulness. Yet, only a justification under a primary norm can preclude wrongfulness. Moreover, the distinction between primary and secondary rules oversimplifies the complexity of some legal norms. ${ }^{27}$ Only very few norms are absolute and in most circumstances the primary norms will provide for exceptions. It is therefore inaccurate to conflate such exceptions with situations where there was a doubtless breach at the primary level but no responsibility was incurred. Indeed, justifications regulate the content of the primary norm, but this is not what the secondary rules of state responsibility ought to do. State responsibility regulates the consequences of a breach. ${ }^{28}$ Thus, under the law of state responsibility, only responsibility for wrongfulness can be precluded, but not wrongfulness itself. The problem of differentiation will now be discussed in the use of force context.

\footnotetext{
${ }^{23}$ ARSIWA with Commentaries, Commentary to Article 24, para 2.

24 Commentary to Articles on State Responsibility, Commentary to Article 21.

25 Crawford, supra note 18 , at 443.

26 ibid. at 492.

27 ibid. at 492.

${ }^{28}$ ARSIWA, General Commentary, para 4(a).
} 
B. Defending the use of force: a typology of justifications and excuses

The borderline between justifications and excuses is sometimes blurred even in municipal legal systems. Andrew Botterell explains that a system of criminal law may accept the choice of the lesser evil, which is linked to the defence of necessity, as a justification 'for conduct that would otherwise be a crime if ... [the actor] believes that the conduct is necessary to avoid a harm or evil to herself or to another person that is greater than the harm or evil sought to be prevented by the law defining the crime.'29 In order to claim such a justification, it needs to be proven that a greater evil was prevented. It is unclear, however, where the justification ends and excuse begins, as 'much conduct that fails to prevent greater evil will not be excusable conduct either.'30 This is also true in international law. While the use of force can be authorised, that is, legally warranted by the Security Council and thus a justification, it is clearly defined as the choice of the lesser evil. Indeed, force is only warranted where peaceful 'measures provided for in Article 41 would be inadequate or have proved to be inadequate.'31

Commenting on the 2003 use of force against Iraq, Susan Marks put it: If all it would have taken to make the war in Iraq legal was a few more votes in the Security Council, then perhaps at least some of the energy that is going into affirming the illegality of the war should be turned to the question of whether there is something wrong with international law.'32 This observation indicates the need for the Security Council to consider carefully what the lesser evil is when it justifies the use of force. J ust like in a domestic setting, also in the international law on the use of force, the lesser evil can be a defence operating in both concepts, justifications and excuses.

Outside of justifications, the lesser evil reasoning has been in the background of reasoning behind humanitarian intervention without Security Council's

29 Botterell, supra note 3, at 179. In this context, a possible excuse under domestic criminal law would be 'mistaken self-defence', but a thorough discussion is beyond the scope of this article. See Bottorrell, supra note 3 , at 174 .

30 ibid.

31 Art. 42 UN Charter.

32 S. Marks, 'State-Centrism, International Law, and the Anxieties of Influence', 19 LJIL (2006) 339, at 347. 
authorisation. ${ }^{33}$ When presented with a grave humanitarian situation and human suffering, states may consider what the lesser evil' is: observing an upcoming genocide and respecting the rules on the use of force, or breaching the law to prevent the genocide. As Commentary to Article 25 provides, unlike distress, necessity does not cover situations in which lives of individuals could be endangered, but a grave danger exists 'either to the essential interests of the State or of the international community as a whole. ${ }^{34}$ This suggests that responsibility for wrongfulness could be precluded where a primary norm is breached in order to address a grave humanitarian situation.

The Kosovo intervention in 1999 created the effect of 'frustrated legal formalists'. This effect is perhaps best captured in the writing of Christine Chinkin:

How can I, as an advocate of human rights, resist the assertion of a moral imperative on states to intervene in the internal affairs of another state where there is evidence of ethnic cleansing, rape and other forms of systematic and widespread abuse, regardless of what the Charter mandates about the use of force and its allocation of competence?35

Bruno Simma talked about a 'thin red line' that separated the intervention from being legal, 36 to which Antonio Cassese responded that the red line was not thin at all. ${ }^{37}$ According to Cassese, the line separating legal and illegal use of force had doubtlessly been crossed, but in the particular case this was not a bad thing. Cassese separated law and ethics, and concluded: '[F]rom an ethical viewpoint resort to armed force was justified. Nevertheless, as a legal scholar I cannot avoid observing in the same breath that this moral action is contrary to current international law.'38

The frustration was obvious. A legal scholar interpreting international law de lega lata in good faith could not conclude that the intervention was legal. At the same time, a legal scholar committed to human rights could not deny that the intervention ended atrocities and a grave humanitarian situation in Kosovo. The phrase illegal but

\footnotetext{
33 Sloane, supra note 8 , at 476.

34 ARSIWA with Commentaries, Commentary to Article 25, para 2 (emphasis added).

35 ARSIWA with Commentaries, Commentary to Article 25, para 2 (emphasis added).

36 B. Simma, 'NATO, the UN and the Use of Force: Legal Aspects', 10 EJ IL (1999) 1, at 6.

37 A. Cassese, 'Ex Iniuria Ius Oritur: Are We Moving Towards International Legitimation of Forcible Humanitarian Countermeasures in the World Community?', 10 EJ IL (1999) 23, at 24- 25.

38 ibid. 25 (emphases in original).
} 
legitimate' emerged out of this frustration, which suggests that sometimes the prudent response will not be obeying the law but breaching it. This reasoning reflects a typical argument for defences known in municipal law: illegal use of force is the choice of the lesser evil. ${ }^{39}$ And here it was acknowledged that the lesser evil was not justified. Rather, a subtle plea was made for it to be excused. When it comes to the use of force, the choice of the lesser evil can thus underlie both, a justification and an excuse. It is clear, however, that it can only work as a justification where the use of force is authorised by the Security Council.

The boundary between a justification and an excuse can also be blurred in selfdefence. In international law, self-defence is a clear-cut justification, as it is a legallywarranted action under Article 51, UN Charter. ${ }^{40}$ This is less clear with the extra-Charter concept of anticipatory self-defence. Article 51 of the UN Charter warrants the use of force where an armed attack has occurred. This wording excludes anticipatory selfdefence. Nevertheless, it is often argued that anticipatory self-defence is a customary exception to the prohibition of the use of force and precedes the UN Charter. ${ }^{41}$ If this were the case, anticipatory self-defence would also be a justification for the use of force, warranted by customary international law. The doctrine goes back to the well-known 1837 Caroline incident between Great Britain and the United States. Doubts exist, however, whether anticipatory self-defence really was a customary rule then and, indeed, whether it is now. ${ }^{42}$ The ICJ has avoided taking a position on this issue. ${ }^{43}$ Rather than self-defence, Special Rapporteur Crawford noted that: The "Caroline" incident of 1837, though frequently referred to as an instance of self-defence, really involved the plea of necessity at a time when the law concerning the use of force had a quite different basis than it has at present.' 44 This is concluded on the basis of correspondence between

\footnotetext{
${ }^{39} \mathrm{cf}$. supra note 29.

40 cf. supra note 11.

${ }^{41}$ For a comprehensive overview see J. Green, Docking the Caroline: Understanding the relevance of the formula in contemporary customary international law concerning self-defence', 14(2) Cardozo J ournal of International and Comparative Law (2006) 429.

42 See J. Green and F. Grimal, The Threat of Force as an Action in Self-Defense Under International Law, 44 Vanderbilt J ournal of Transnational Law (2011) 285, at 302.

43 ibid.

${ }^{44}$ ARSIWA, Commentary to Article 25, para 5.
} 
the governments of Great Britain and the United States in which the discussion on necessity of the use of force played a prominent role. 45

A thorough discussion on the Caroline incident would go beyond the scope of this article. In terms of the post-1945 international law, it is conceptually difficult to accept that anticipatory self-defence as a justification under customary international law could prevail over its narrower Charter scope simply because (alleged) custom precedes the Charter. This appears to go against Article 103, UN Charter, which provides that obligations arising under the Charter take precedence over any other international obligation. ${ }^{46}$ If the Charter obligation authorises the right to use force only when an armed attack has occurred, this should take precedence over any broader justification of the use of force arising under another source of law. Even if such custom existed prior to 1945, the Charter rules on the use of force would have modified it. The conceptual difficulty with having a customary justification broader than what the Charter allows is thus another reason why anticipatory self-defence could be seen as an illegality, defendable under the doctrine of necessity; but not a customary justification.

As explained above, necessity in the use of force can be a justification in the context of the Security Council's authorisation of the use of force as the choice of the lesser evil. ${ }^{47}$ Furthermore, necessity is also a concept operating within Article 51 selfdefence. As established by the ICJ in the Nicaragua case, 'whether the response to the attack is lawful depends on the observance of the criteria of the necessity and proportionality of the measures taken in self-defence.' 48 It is important to note that the ICJ here discussed necessity limited to the scope of Article 51 and did not consider anticipatory self-defence. In (domestic) criminal law, self-defence is justifiable as long as

\footnotetext{
45 See Letter from Daniel Webster to Henry S. Fox (24 April 1841), in 29 British and Foreign State Papers (1841-42), at 1129- 39 (1857).

46 Art. 103 UN Charter. Article 103 textually refers to 'any other agreement' and the drafting history of the Charter suggest that its superiority is limited to treaty law; however, international law has evolved since then and nowadays Article 103 should be understood as prevailing over any other international legal obligation, treaty-based or customary. See M. Milanovic, 'Norm Conflict in International Law: Whither Human Rights?', (2009) 20 Duke J ournal of Comparative and International Law 69, at 78- 79. Indeed, many obligations arising under multilateral treaties are also reflected in customary law. Article 103 would remain somewhat toothless if it only prevailed over a treaty provision sensu stricto and could not bite against a 'treaty reflection' in customary law. In many instances states could then invoke customary law in order to get out of the Charter obligations.

47 See supra note 31.

48 Military and Paramilitary Activities in and against Nicaragua (Nicaragua v United States of America), Merits, ICJ 1986, para 194.
} 
it is within the limits of necessity and proportionality, but mistaken or excessive selfdefence is capable of being excused. ${ }^{49}$ In international law, necessity can also be an "under-labourer" of self-defence, but it is not a self-standing justification. It can be an excuse, however. Indeed, in the law of state responsibility, it is conceptualised as a defence for an act which is deliberately wrongful.

Analogously to the theory of defences in a domestic setting, even in international law, necessity can operate within justifications and excuses. As a justification, it operates within Article 51, UN Charter, but it works as an excuse in the doctrine of anticipatory self-defence. Following Crawford's commentary on the Caroline incident, an attack conducted on a territory of another state could be excused under extreme circumstances where it 'is the only way for the State to safeguard an essential interest against a grave and imminent peril.'50 It is thus arguable that where a state acts in "anticipatory selfdefence," this action is not justified under the law governing the use of force, but rather excused under the law of state responsibility.

Consent is another defence which is relevant (also) in the use of force context. As Gregory Fox argues, where a government invites another state to intervene, this is a 'mitigation through consent ... consistent with principles of state responsibility, which provide that consent to an otherwise unlawful act precludes the wrongfulness of that act.'51 Consent is elaborated in Article 20, ILC Articles on State Responsibility: 'Valid consent by a State to the commission of a given act by another State precludes the wrongfulness of that act in relation to the former State to the extent that the act remains within the limits of that consent. ${ }^{52}$ Special Rapporteur Crawford notes that it may be rather odd to define consent as a circumstance precluding wrongfulness, as it 'renders the conduct intrinsically lawful', where 'validly given in advance.'53 Where consent is given for, e.g., passage through territorial waters, no wrongfulness has occurred. It is a

\footnotetext{
49 J. Goudkamp, Tort Law Defences (Hart, 2013), at 89-90. See also N. Shah, 'Self-defence, Anticipatory Self-defence and Pre-emption: International Law's Response to Terrorism', 12 Journal of Conflict and Security Law (2007) 95, at 95. Shah contextualises self-defence in international law with the concept of self-defence in municipal legal systems.

50 Art. 25 (1) (a) ARSIWA.

51 G. Fox, 'Intervention by Invitation', in M. Weller, The Oxford Handbook on the Use of Force (OUP, forthcoming in 2015), at 1, available at http:// papers.ssrn.com/ sol3/ papers.cfm?abstract_id=2407539.

52 G. Fox, 'Intervention by Invitation', in M. Weller, The Oxford Handbook on the Use of Force (OUP, forthcoming in 2015), at 1, available at http:// papers.ssrn.com/ sol3/ papers.cfm?abstract_id=2407539.

53 G. Fox, 'Intervention by Invitation', in M. Weller, The Oxford Handbook on the Use of Force (OUP, forthcoming in 2015), at 1, available at http:// papers.ssrn.com/ sol3/ papers.cfm?abstract_id=2407539.
} 
legally warranted exception to the general rule and as such a justification. This is different than being in territorial waters of another state without its consent, yet when the vessel is in distress. In this case wrongfulness has occurred but distress can be invoked as an excuse and responsibility for wrongfulness will not be incurred.'54 Thus, it is indeed correct to term consent as a circumstance that precludes wrongfulness, while e.g. distress and necessity only mitigate against responsibility for wrongfulness.

It is beyond the scope of this article to consider when consent in the context of intervention by invitation is valid and issued by the right authority. ${ }^{55}$ As noted in the Commentary to Article 20, ILC Articles in State Responsibility, '[w] hether consent has been validly given is a matter addressed by international law rules outside the framework of State responsibility.'56 It should be recalled, however, that in the Nicaragua case, the ICJ had to consider whether consent can be given (i.e. request for an intervention issued) by an opposition group. The Court concluded:

[T] he principle of non-intervention derives from customary international law. It would certainly lose its effectiveness as a principle of law if intervention were to be justified by a mere request for assistance made by an opposition group in another State ... it is difficult to see what would remain of the principle of nonintervention in international law, if intervention which is already allowable at the request of the government of a State, were also to be allowed at the request of the opposition. ${ }^{57}$

It follows from this position that intervention by invitation, where requested by the right authority, can serve as a justification of the use of force. In such circumstances, Article 2(4) is inoperative ... because there is no use of force of one State against another, but two States cooperating together within an internal strife. 58

Consent and Article 51 self-defence are good examples of justifications, while distress and necessity are examples of excuses. In the use of force context, consent is

54 G. Fox, 'Intervention by Invitation', in M. Weller, The Oxford Handbook on the Use of Force (OUP, forthcoming in 2015), at 1, available at http:// papers.ssrn.com/ sol3/ papers.cfm?abstract_id=2407539.

55 G. Fox, 'Intervention by Invitation', in M. Weller, The Oxford Handbook on the Use of Force (OUP, forthcoming in 2015), at 1, available at http:// papers.ssrn.com/ sol3/ papers.cfm?abstract_id=2407539.

56 G. Fox, 'Intervention by Invitation', in M. Weller, The Oxford Handbook on the Use of Force (OUP, forthcoming in 2015), at 1, available at http:// papers.ssrn.com/ sol3/ papers.cfm?abstract_id=2407539.

57 The Nicaragua case, supra note 48 , para 246.

58 The Nicaragua case, supra note 48, para 246. 
manifested in the concept of intervention by invitation where wrongfulness is indeed precluded. It has been shown that the extra-Charter concept of anticipatory self-defence may well belong to the excuse of necessity rather than self-defence. As such, it is a different type of defence than self-defence under Article 51, UN Charter. The act itself remains wrongful, but responsibility for wrongfulness can be mitigated against. The same reasoning can be applied to humanitarian intervention without Security Council's authorisation.

C. Are excuses suitable for the system of international law?

Sloane argues that duress and the choice of the lesser evil are suitable defence in municipal criminal law but should be inapplicable in the law of state responsibility, which deals neither with individuals nor crimes. ${ }^{59}$ The latter defence is also problematic in international law because it requires careful weighing and consideration of circumstances - an exercise which requires a comprehensive judicial system. We do not have an adequate judicial system in international law. 60

The criticism is certainly valid. Individual criminal defences are premised on the assumption that we are dealing with human beings, made of flesh and bones; they are on the one hand rational, but sometimes also irrational and prone to acting emotionally in difficult situations. Pressure on or threats to human beings are thus different from pressure or threats directed against states. ${ }^{61}$ However, certain acts of individuals, who are susceptible to pain and fear, can be attributed to states under the law of state responsibility. ${ }^{62}$ For example, a pilot who violates the airspace of a foreign state in distress is doing so in order to save his life, but the violation is, prima facie, attributable to the state. 63 If one conceptualises excuses as being applicable only to wrongful acts committed when threated with a gun, direct analogies with state responsibility are indeed difficult to make. But one should not forget that it is ultimately the acts of individuals, who may sometimes be threated or in distress, which are attributable to states.

\footnotetext{
59 ibid. $473-474$.

60 ibid. $480-481$.

61 ibid. 473- 474.

62 ibid. $473-474$.

63 ibid. 473- 474.
} 
While the typology of defences is indeed most thoroughly developed in criminal law, it is also known in torts, from which the law of state responsibility borrows heavily. ${ }^{64}$ Hence, the non-criminal nature of the rules of state responsibility does not automatically mean that defences cannot be differentiated. It is rather questionable whether an analogy with domestic legal systems can be made for this purpose and whether one can assume that excuses under the secondary rules of state responsibility would not start affecting the scope of the primary norm.

These questions have been thoroughly discussed by Anthea Roberts, especially with regard to the legal/legitimate dichotomy. ${ }^{65}$ Although Roberts asks whether illegal use of force can be justified, she refers to what I propose to be conceptually separated and termed excused. Roberts gives a negative answer and the reason for scepticism is valid: the nature and structure of international law. ${ }^{66}$ Her scepticism is premised on similar considerations as Sloane's: in municipal legal orders, we have an organised system of judiciary which provides for an authoritative case-bycase decision on when a certain wrongful conduct may be excused - whether it indeed was the lesser evil. ${ }^{67}$ We do not have that in international law and the system could result in a mess. States are already overtly creative when it comes to interpretation of the rules on the use of force; we certainly do not need to introduce a concept that would make their defences of illegal uses of force even easier. 68

Furthermore, as Roberts rightly points out, international law is a rather peculiar legal system in which the behaviour of its primary actors also has effects for law-making (state practice relevant for customary international law) as well as for interpretation of presently-applicable treaty provisions. ${ }^{69}$ Illegal uses of force, especially if internationally tolerated, could thus provide evidence of state practice for development of new customary justifications of the use of force, as well as serve as a base for reinterpretation of Article 2(4) of the UN Charter. ${ }^{70}$ In other words, excuses would not stay in the sphere of secondary rules of state responsibility; eventually they

64 Goudkamp, supra note 49 , at 85.

65 Roberts, supra note 9, at 182- 184 .

66 ibid. at 198.

67 ibid. at 189.

68 ibid. at 198.

69 ibid. 196- 97.

70 ibid. 
could also change primary rules governing the use of force. The boundary between primary and secondary rules is, again, too porous. Roberts rightly observes that although initially presented as a sui generis situation which creates no precedent, Kosovo has frequently been invoked as a precedent by the proponents of relaxation of the rules on the use of force. ${ }^{71}$

A way out of the problem presented by Roberts is to clearly and systematically separate justifications and excuses which are now conflated in the ILC Articles. ${ }^{72}$ The former belong to the primary rules of the use of force and the latter to the secondary rules of state responsibility. A systematic separation of justifications and excuses, therefore, does not come with the peril that the accepted excuses could expand on justifications and thus undermine the strength of the primary norm itself. But the lack of a centralised compulsory jurisdiction to consider excuses on an individual basis certainly remains a potent problem in international law.

To overcome this problem, one possibility could be to look to the practice of UN organs and certain legal concepts that imply a degree of centralisation in international law. With regard to Kosovo, Ian J ohnstone suggests to look at the practice of the Security Council and General Assembly. ${ }^{73}$ Russia proposed a Security Council resolution to condemn the 1999 intervention, but it was rejected in a comfortable twelve-to-three vote. ${ }^{74}$ And neither was the intervention condemned by the General Assembly. Although not directly legally binding, General Assembly resolutions can be relevant indicators of opinio juris, ${ }^{75}$ perhaps even evidence of state practice. ${ }^{76}$ According to J ohnstone, it is highly significant that the General Assembly remained silent. ${ }^{77}$ This may well indicate acceptance of the outcome by acquiescence.

Although Johnstone's proposition has some merit, it comes with two problems. First, voting behaviour in UN bodies is a strong indicator of state practice, but not the only one. A number of states, including China and Russia, condemned the

\footnotetext{
71 ibid. 198.

72 See supra note 14.

$73 \mathrm{~J} \mathrm{ohnstone,} \mathrm{supra} \mathrm{note} 4$, at 365.

74 ibid.

75 The Nicaragua case, supra note 48, para 188.

${ }^{76}$ For a thorough discussion on whether resolutions of UN bodies could be indicative of state practice, opinio juris, or both see M. Divac Öberg, The Legal Effects of Resolutions of the UN Security Council and General Assembly in the J urisprudence of the ICJ', 16 EJ IL (2006) 879, at 898-900.

$77 \mathrm{~J}$ ohnstone, supra note 4 , at 365.
} 
intervention fiercely and doubtlessly in their statements. ${ }^{78}$ Even in the absence of a condemnatory resolution, the acceptance of the intervention was far from being uniform. And uniformity or near-uniformity is required if any legal consequences are to be drawn on the basis of state practice and opinio juris. ${ }^{79}$ Secondly, even if there is no condemnation from UN organs, states can still be bound by general international law not to accept an illegal situation. Since we are dealing here with illegal use of force, the obligation arising from Article 41 of the ILC Articles on State Responsibility applies. 80 States are under the obligation to withhold recognition of a situation created by a serious breach of a peremptory norm, regardless of whether or not the Security Council adopts a resolution to this effect. ${ }^{81}$

The legality/legitimacy dichotomy in the context of the use of force essentially builds on the logic of excuses: it is not denied that the act was wrongful, but in the circumstances it was the lesser evil' and should be excused. Yet, who decides on the plausibility of an excuse in a decentralised international legal system? J ohnstone proposes that excuses for illegal uses of force have been accepted by acquiescence. This contention is problematic. Below, an argument will be made that practice may well have developed which was universal and went beyond mere acquiescence.

\section{Defences, use of force and State responsibility: An interim conclusion}

Shortly after the ILC Articles on State Responsibility were drafted, David Caron cautioned that they were the outcome of a lengthy process, subject to difficult compromises, and reflect the work of several Special Rapporteurs. ${ }^{82}$ Although an impressive piece of work, they also had too many cooks who, in some respects, spoiled the broth. The Articles now need to be consummated with a grain of salt. Although written in a form that imitates a treaty, they should not be interpreted as a treaty but as a combination of a rough description of custom and the ILA's attempt at progressive

\footnotetext{
78 For an analysis of the responses to the use of force against the FRY see D. Kritsiotis, The Kosovo Crisis and Nato's Application of Armed Force Against the Federal Republic of Yugoslavia', 49 ICLQ (2000) 330, at 344 .

79 cf. supra note 75 .

80 Art. 41 ARSIWA.

81 ibid. Commentary to Article 41 refers to a number of situations where Security Council resolutions existed but were not legally-binding.

82 D. Caron, The ILC Articles on State Responsiblity: The Paradoxical Relationship between Form and Authority', 96 AJ IL (2002) 857, at 857.
} 
development of international law. 83 The ILC Articles thus provide a framework of the law on state responsibility, but applying this framework rigidly can lead to logical inconsistencies.

The ILC Articles on State Responsibility conflate justifications and excuses which should be seen as two distinct concepts - even in international law. As Lowe illustrates: "The distinction between the two is the very stuff of classical tragedy. No dramatist, no novelist would confuse them. No philosopher or theologian would conflate them.' 84 The law of state responsibility is said to be a body of secondary rules governing the consequences of a breach of a primary norm. In fact, the distinction is not as rigid as is sometimes presented. The law of self-defence is a good example. Rather than dealing with responsibility for a breach, it determines when the primary norm was not breached at all. In the ILC Articles, self-defence is indeed included under the circumstances that preclude wrongfulness. But wrongfulness can only be precluded when primary norms allow for justification, such as Article 51, UN Charter. On the other hand, the Articles include circumstances which, in fact, do not preclude wrongfulness under primary norms but mitigate against responsibility for breaches of primary norms. These are excuses and here we truly remain on the level of the secondary rules of state responsibility.

I thus propose to go beyond the title of Chapter V of Part One in the ILC Articles and establish a twofold distinction: circumstances precluding wrongfulness (justifications under primary norms) and circumstances mitigating against responsibility for breaches of primary norms (excuses under the law of state responsibility). Self-defence under Article 51, UN Charter, and consent are examples of the former; necessity and distress of the latter. It has already been demonstrated that the use of force may be seen as the choice. It may not only be conceptualised as a legally warranted justification, but under the defence of necessity also an excuse where force is used unlawfully.

However, some concepts in the law of state responsibility would suggest that excuses to unlawful use of force should not be conceptually possible, only justifications. It is further problematic that international law may not have the necessary

83 ibid. 858-61.

84 Lowe, supra note 4 , at 406. 
tools to weigh the circumstances where exceptions may be claimed. An argument will be made that to a limited extent these problems have been resolved in practice of states and UN organs.

\section{Excusing illegal use of force: the ILC Articles and contradicting state practice}

Commentary to Article 25 of the ILC Articles on State Responsibility provides that the defence of necessity could be available where a grave danger exists 'either to the essential interests of the State or of the international community as a whole.' ${ }^{\prime 5}$ Can necessity be used as an excuse where force is used illegally as the lesser evil' in order to address the danger for the international community as a whole?

When it comes to an unjustified use of force, the problem arises that it violates a peremptory norm. This has consequences under the law of state responsibility. Article 26 of the ILC Articles provides that '[n]othing in ... [the chapter on the circumstances precluding wrongfulness] precludes wrongfulness of any act of a State which is not in conformity with an obligation arising under a peremptory norm of general international law.'86 The content of the concept of peremptory norms is contested, but for the purposes of this article it will be assumed that prohibition of illegal use of force belongs to this circle. ${ }^{87}$ The adjective 'illegal' is of notable significance here. Unlike the prohibitions of torture, slavery, apartheid and genocide, also widelyaccepted peremptory norms, the prohibition of the use of force knows of lawful exceptions, that is, justifications. ${ }^{88}$ Hence the need to qualify the prohibition and its peremptory character with the adjective. Not any use of force is a violation of a peremptory norm, but only use of force that cannot be justified under primary norms. An unjustified (or illegal) use of force should, however, constitute a jus cogens violation.

\footnotetext{
${ }^{85}$ ARSIWA with Commentaries, Commentary to Article 25, para 2 (emphasis added).

86 Art. 22 ARSIWA.

87 The list of peremptory norms is contested and no formal source of international law identifies them. Some guidelines follow from academic writings and judicial decisions. A good overview of the most generally accepted peremptory norms is given in the Commentary to Article 40 of the Articles on State Responsibility where the following norms are mentioned: the prohibition of torture, the prohibition of genocide, the prohibition of racial discrimination, the prohibition of slavery, the prohibition of the illegal use of force, the basic rules of humanitarian law, and self-determination. ARSIWA, Commentary to Article 40.

$88 \mathrm{cf}$. supra notes 10 and 11.
} 
A. Excusing jus cogens violations: some conceptual problems

If one reads Article 26 literally, it only covers justifications: wrongfulness cannot be precluded. However, it was argued above that the chapter on the circumstances precluding wrongfulness conflates the circumstances that indeed preclude wrongfulness under primary norms and circumstances that mitigate against responsibility under secondary rules. ${ }^{89}$ The question thus arises whether Article 26 should also be read more broadly and understood as a barrier against precluding responsibility for violations of jus cogens.

The effects of the peremptory norms under Article 26 need to be contextualised with Articles 40 and 41. Article 40 establishes international responsibility for a serious breach of a peremptory norm, ${ }^{90}$ while Article 41 regulates the consequences of such a breach. When a breach occurs on the primary level, it creates an obligation erga omnes for the international community as a whole not to recognise the situation as lawful, 'nor render aid or assistance in maintaining that situation.'91 Commentary to Article 41 specifies that the obligation has effects not only for the responsible state and the rest of the international community, but also for the injured state:

[T] he responsible State is under an obligation not to recognize or sustain the unlawful situation arising from the breach. Similar considerations apply even to the injured State: since the breach by definition concerns the international community as a whole, waiver or recognition induced from the injured State by the responsible State cannot preclude the international community interest in ensuring a just and appropriate settlement. ${ }^{92}$

It follows that wrongfulness arising from a breach of a peremptory norm cannot be precluded by recognition of the effective situation, granted either by the injured state or foreign states. This is mutatis mutandis similar to Article 26: wrongfulness arising under a breach of a peremptory norm cannot be precluded. Moreover, Article 41 creates obligations for the international community as a whole. It is not only that international

\footnotetext{
89 See supra note 14.

90 Art. 40 ARSIWA.

${ }^{91}$ Art. 41(2) ARSIWA.

${ }_{92}$ ARSIWA with Commentaries, Commentary to Article 41, para 9.
} 
responsibility is incurred by the wrongdoing state, all states - including the injured one - have a duty to withhold recognition, so that a jus cogens violation would not be given legal effect.

The doctrine of non-recognition has developed since the Japanese occupation of Manchuria and annexations of Fascist Italy and Nazi Germany. ${ }^{93}$ After the end of the Second World War, it continued with non-recognition of South Africa's presence in Namibia, ${ }^{94}$ the declaration of independence of Southern Rhodesia, ${ }^{95}$ the emergence of the Homelands as states 'independent' from apartheid South Africa, ${ }^{96}$ the emergence of the Turkish Republic of Northern Cyprus, ${ }^{97}$ and the Iraqi annexation of Kuwait. 98 The peremptory norms involved in these situations were the right of selfdetermination, the prohibition of racial discrimination, and the prohibition of illegal use of force, although in some instances more than one of these norms was at stake. In all of these situations, the international community reacted through the Security Council or the General Assembly. Resolutions of these UN organs were adopted which called on all states to withhold recognition of territorial illegality. However, Chapter VII resolutions of the Security Council were an exception rather than rule. ${ }^{99}$ The binding authority to withhold recognition thus rarely came from the Security Council's Chapter VII powers. It was rather applicable under general international law.

Notably, all examples in the Commentary to Article 41 refer to situations of illegal territorial acquisition or illegal state creation. 100 This implies that the duty to withhold recognition in the context of Article 41 refers to the concept of recognition operating in the law of statehood and territorial illegality. Some might challenge this proposition. As Ian Brownlie indeed noted, 'recognition' is a term used also in other

\footnotetext{
93 For details see J . Dugard, Recognition and the United Nations (Grotius Publications, 1987) at 37-40, 94 Legal Consequences for States of the Continued Presence of South Africa in Namibia (South West Africa) notwithstanding Security Council Resolution 276 (1970), ICJ , Advisory Opinion of 21J une 1971. 95 SC Res. 202, 6 May 1965; SC Res. 216, 12 November 1965; SC Res. 217, 20 November 1965; SC Res. 277, 18 March 1970.

96 SC Res. 402, 22 December 1976; SC Res. 407, 25 May 1977.

97 SC Res. 353, 20 July 1974; SC Res. 541, 18 November 1983.

98 SC Res. 661, 6 August 1990.

99 Only Resolution 277 after Southern Rhodesia declared itself a republic, and Resolution 661 after Iraqi occupation of Kuwait were adopted under Chapter VII. In other situations, the Security Council called for non-recognition in legally non-binding resolutions.

100 ARSIWA with Commentaries, Commentary to Article 41, paras 6 - 10.
} 
areas of international law, for example recognition of immunity. ${ }^{101}$ This is not the place to discuss whether (non-)recognition referred to in Article 41 applies beyond the situations of territorial illegality. In any case, it needs to be kept in mind that recognition in international law is a term of art, and Article 41 does not apply whenever the word 'recognition' can be used in plain language. It is probably not a coincidence that the Commentary to Article 41 does not use any examples of non-recognition other than those referring to occupation or illegal state creation.

In the context of the use of force which cannot be justified under primary rules, ${ }^{102}$ Article 26 precludes the injured states as well as the international community as a whole from releasing the wrongdoing state from responsibility for the breach. Moreover, Article 41 prohibits recognition of a shift of territorial sovereignty as a result of the use of force. However, at least the latter has happened before in instances where force was used unjustifiably, yet as the choice of a lesser evil. Although Roberts and Sloane are correct in claiming that international law does not have a comprehensive judicial system to judge the excuses of the lesser evil, ${ }^{103}$ voting behaviour in UN organs and the concept of recognition may well have played such a role and, at least implicitly, excused uses of force that were unjustified and thus internationally wrongful.

\section{B. Crimea versus Kosovo}

In 2014, Crimea declared independence from Ukraine and its integration with Russia. 104 The Crimean move was backed by Russia militarily and the latter's involvement constitutes at least a threat if not an actual use of force. ${ }^{105}$ With regard to the use of force, Russia tried to provide justification under the self-defence exception, and claimed it acted under the controversial protection-of-nationals doctrine.106 A thorough

\footnotetext{
101 I. Brownlie, 'Recognition in Theory and Practice', 53 BYIL (1982) 197, 200-201. See also A. Orakhelashvili, 'State Immunity and Hierarchy of Norms: Why the House of Lords Got It Wrong', 18 EJ IL (2008), 955, at 964- 65.

102 See supra notes 10 and 11.

103 See supra notes 60 and 69.

104 BBC News, 'Ukraine crisis: A Guide to Russia's Vision of Crimea' (25 March 2014), at $<$ http:// www.bbc.com/news/ world-europe-26695808>.

105 See N. Krisch, 'Crimea and the Limits of International Law', EJ IL Talk! (10 March 2014), at $<$ http:// www.ejiltalk.org/ crimea-and-the-limits-of-international-law>.

106 See D. Wisehart, The Crisis in Ukraine and the Prohibition of the Use of Force: A Legal Basis for Russia's Intervention?' EJ IL Talk! (4 March 2014), at <http:/ / www.ejiltalk.org/ the-crisis-in-ukraine-andthe-prohibition-of-the-use-of-force-a-legal-basis-for-russias-intervention>.
} 
discussion on the doctrine is beyond the scope of this article. For its purposes it should be recalled that even if one were willing to proceed on the protection-of-nationals doctrine in principle, the threshold of violence against Russian nationals in Crimea to trigger this type of self-defence would not have been met in any case. ${ }^{107}$ And even if Russia's use of force were justified under the law of self-defence, it would not have given Russia the right to annex a Ukrainian territory. In essence, Russia cannot provide any justification for the use of force and Crimean secession is illegal due to Russia's military backing. The obligation to withhold recognition of the effective situation applies under Article 41 of the ILC Articles on State Responsibility, even for Russia; ${ }^{108}$ but the latter is the only state that recognises the new effective territorial situation. Save for Russia, the international legal responses to the Crimean situation thus seem to be entirely in line with the framework of the law of state responsibility. The outcome was different in Kosovo. What makes Kosovo different in law if compared to Crimea?

As argued above, in 1999 NATO used force against the FRY and under primary norms this force is generally seen to have been used illegally. ${ }^{109}$ In the same year, the Security Council adopted Resolution 1244 which did not grant Kosovo independence but rather created a legal regime of international territorial administration and governance in separation of the FRY and Serbia. ${ }^{110}$ In 2008, Kosovo declared independence. ${ }^{111}$ To date, it has been recognised by 108 states. ${ }^{112}$ In 2010, the ICJ delivered the Kosovo Advisory Opinion, which focused on the declaration of independence itself rather than the law of statehood more generally. The Advisory Opinion is thus often criticised for being too narrow. ${ }^{113}$ But in many respects the

107 ibid. It is also questionable whether we are talking here of Russian nationals in Ukraine, or rather ethnic Russians who are Ukrainian nationals.

108 ARSIWA with Commentaries, Commentary to Article 41, para 9, inter alia, provides: 'Evidently, the responsible State is under an obligation not to recognize or sustain the unlawful situation arising from the breach [of a peremptory norm].'

109 See also S. Talmon, 'At last! Germany Admits Illegality of the Kosovo Intervention', forthcoming in

German Yearbook of International Law, available at http:// papers.ssrn.com/sol3/ papers.cfm?abstract_id=2508286

110 SC Res. 1244, 10 J une 1999.

111 Republic of Kosovo, Assembly, Kosovo Declaration of Independence (17 February 2008), at $<\mathrm{http}: / /$ www.assembly-kosova.org/ ?cid=2,128,1635>.

112 See Who Recognized Kosovo as an Independent State?, at <http:// www.kosovothanksyou.com>.

113 See J. Cerone, The World Court's Non-Opinion', Opinio Juris (25 July 2010), at <http:// opiniojuris.org/2010/07/25/the-world-court\%e2\%80\%99s-non-opinion>. For a more thorough discussion on the matter see H. Hannum, The Advisory Opinion on Kosovo: An Opportunity Lost, or a Poisoned Chalice Refused?' 
Opinion is not as narrow as it seems. Particularly instructive is the ICJ 's pronouncement that:

[T] he illegality attached to [some other] declarations of independence ... stemmed not from the unilateral character of these declarations as such, but from the fact that they were, or would have been, connected with the unlawful use of force or other egregious violations of norms of general international law, in particular those of a peremptory character (jus cogens). ${ }^{114}$

With this pronouncement, the ICJ confirmed that in some circumstances even a declaration of independence itself may be unlawful. These are situations covered by Article 40 and trigger Article 41 of the ILC Articles on State Responsibility: violations of jus cogens. ${ }^{115}$ Moreover, the ICJ thereby accepted that unlike some other situations (e.g. Northern Cyprus, Southern Rhodesia), ${ }^{116}$ there was no such breach in Kosovo. The ICJ thus at least implicitly affirmed that recognition of Kosovo was not illegal under international law and Article 41 was not engaged when independence was declared in 2008. This is despite the fact that the use of force in 1999 was illegal under the primary rules on the use of force. What are thus the combined effects of the actions of two UN organs, the Security Council (Resolution 1244) and the ICJ (Kosovo Advisory Opinion)? Article 41, ILC Articles on State Responsibility, inter alia requires from states not to 'render aid or assistance in maintaining ... [a] situation [created in violation of jus cogens].'117 Notably, Resolution 1244 did not justify ex post the illegal use of force in Kosovo. It did not provide an authority that would subsequently preclude wrongfulness of the use of force against the FRY. In other words, Resolution 1244 did not provide for a justification under the primary rules governing the use of force. Instead, the Resolution accepted the outcome of the illegal use of force: Kosovo's governance in separation from Serbia and the FRY, as well as a foreign military and civilian presence. ${ }^{118}$ Resolution

(2011) 24 LJ IL 155.

114 Accordance with International Law of the Unilateral Declaration of Independence in Respect of Kosovo, Advisory

Opinion of 22 J uly 2010, ICJ , para 81.

115 Articles 40 and 41 ARSIWA.

116 cf supra notes 95- 97.

117 Art. 41(2) ARSIWA.

118 SC Res. 1244, $10 \mathrm{~J}$ une 1999, para 3. 
1244, therefore, nothing but demands from states to render 'aid or assistance in maintaining' a situation created in violation of jus cogens. ${ }^{119}$ The use of force against the FRY was never justified under the primary norms, but Resolution 1244 can be seen as the legal authority that interrupts the link between the illegal use of force and Article 41. In other words, Resolution 1244 did not 'cure' illegality but, on the basis of a humanitarian excuse, prevented some consequences under the law of state responsibility.

Should that be even conceptually possible? How can states be released from a jus cogens obligation? In fact, they were not released out of jus cogens. Prohibition of illegal use of force is jus cogens, but Article 41 is not. Article 41 deals with the consequences of a breach of jus cogens and, as has been firmly established in doctrine and judicial practice, the peremptory character of the norm does not follow to the level of consequences; it does not have a secondary effect. ${ }^{120}$ As follows from the ICJ 's Germany v Italy Immunities case, torture may well be a violation of jus cogens, but it does not create a secondary peremptory obligation to waive immunity. ${ }^{121}$ Given such a narrow interpretation of jus cogens, it also follows that illegal use of force is a violation of a peremptory norm, but the secondary obligation to withhold recognition is not peremptory. Indeed, Article 41 belongs to the secondary rules of state responsibility which by definition cannot be peremptory. The obligation under Article 41 can thus be weighed against other considerations and humanitarian considerations prevailed in the situation of Kosovo.

The conclusion is also supported by the responses to Kosovo's declaration of independence. The opposing states disputed Kosovo's declaration on the basis that it was issued without Serbia's consent. ${ }^{22}$ In doing so, they implied they would happily

\footnotetext{
119 cf Art. 41(2) ARSIWA.

120 See J urisdictional Immunities of the State (Germany v Italy, Greece intervening), Merits, J udgment of 3 February 2012, ICJ, para 83, where the court analysed domestic practice and concluded that only Italian courts had upheld the expansive understanding of jus cogens, and it is precisely this practice which led to the jurisdictional immunities litigation before the ICJ .

121 ibid. para 84.

122 Consider the following argument: 'As soon as the principle of territorial integrity applies, it necessarily outlaws secession without the consent of the parent state. Such understanding avoids systemic inconsistency under which international law would guarantee territorial integrity yet would not prohibit secession.' A. Orakhelashvili, 'Statehood, Recognition and the United Nations System: A Unilateral Declaration of Independence in Kosovo', 12 (2009) Max Planck Yearbook of United Nations Law 1, at 13. See also Accordance with International Law of the Unilateral Declaration of Independence by the
} 
recognise had Serbia consented to independence. However, not even Serbia's consent would 'cure' the original illegality - the illegal use of force. Indeed, the injured state does not have the power to release any other state from international legal obligations, ${ }^{123}$ and particularly not if they are of jus cogens character. ${ }^{124}$ Yet, states can be released out of responsibility to address and not to accept an effective situation created by violation of a primary norm. As has just been demonstrated, on the basis of an excuse, states can even be released from the responsibility to address the consequences of a jus cogens violation, as the obligation to address such consequences is not itself peremptory in nature.

In the end, the Kosovo episode and the illegal use of force; Resolution 1244; declaration of independence; recognitions; and the advisory opinion lead to the conclusion that the humanitarian excuse was accepted on the level of the secondary rules of state responsibility rather than the primary rules governing the use of force. It would be too far-fetched to say that the intervening NATO member states were released from international responsibility for the breach of the rules on the use of force. But it is not only about their international responsibility. The law of state responsibility does not only regulate the relationship between the wrongdoing and the injured state, and it is specifically established that wrongfulness arising from a breach of jus cogens cannot be precluded. ${ }^{25}$ The law of state responsibility also creates obligations for third states and in Kosovo they were released from Article 41, ILC Articles. This is clearly different in the situation of Crimea, where no persuasive excuse was offered.

Kosovo was a more complex situation due to there being a subsequent Chapter VII resolution. It is thus also instructive to look at a similar outcome without

Provisional Institutions of Self-Government of Kosovo, Public sitting held on Friday 11 December 2009, CR 2009/33, 17, para 5 (argument of Nguyen Anh on behalf of Vietnam), arguing even that territorial integrity of states is a norm of jus cogens. Consider also the statement of the representative of Russia in the Security Council's meeting immediately upon Kosovo's Declaration of Independence: 'The Russian Federation continues to recognize the Republic of Serbia within its internationally recognized borders. The 17 February [2008] declaration by the local assembly of the Serbian province of Kosovo is a blatant breach of the norms and principles of international law - above all of the Charter of the United Nationswhich undermines the foundations of the system of international relations. That illegal act is an open violation of the Republic of Serbia's sovereignty, the high-level Contact Group accords, Kosovo's Constitutional Framework, Security Council resolution 1244 (1999) - which is the basic document for the Kosovo settlement-and other relevant decisions of the Security Council.' Statement on Behalf of the Russian Federation, Security Council Meeting on 18 February 2008, UN Doc S/ PV.5839, at 6.

123 See Lowe, supra note 4 , at 406.

124 Art. 26 ARSIWA.

125 ibid. 
any legally-binding Security Council involvement. Considering the difference between Northern Cyprus and Bangladesh is particularly instructive in this regard.

\section{Northern Cyprus versus Bangladesh}

Backed by Turkey's military intervention, Northern Cyprus declared independence in 1983. ${ }^{126}$ Turkey's argument was that force was used in order to protect the ethnically Turkish population from Greek oppression. ${ }^{127}$ However, upon proclamation of independence, the Security Council adopted Resolution 541 in which it, inter alia, called 'upon all States to respect the sovereignty, independence, territorial integrity and non-alignment of the Republic of Cyprus', ${ }^{128}$ and called 'upon all States not to recognise any Cypriot state other than the Republic of Cyprus. '129 Resolution 541 was not adopted under Chapter VII of the UN Charter, but Northern Cyprus has nevertheless not been recognised by any state other than Turkey. ${ }^{130}$ The Commentary to Article 41, ILC Articles on State Responsibility, thus uses Northern Cyprus as evidence of the obligation to withhold recognition of an effective situation created in breach of jus cogens. But the Commentary does not compare this example to that of Bangladesh.

East Pakistan (later called Bangladesh) declared independence from Pakistan in 1971.131 The declaration was issued in the circumstances of severe oppression, possibly even ongoing genocide, of the Bengali people by the central government of Pakistan. ${ }^{132}$ In the same year, India intervened to protect the Bengalis. ${ }^{133}$ There was no Security Council resolution to authorise India's intervention. However, a result of the intervention was, inter alia, that Pakistani forces withdrew from East Pakistan and, being geographically separate from West Pakistan, the eastern part soon became an effective entity capable of demonstrating attributes of statehood. ${ }^{134} \mathrm{~A}$ strong argument can be made that the withdrawal of Pakistani troops 'produced a fait

\footnotetext{
126 D. Raic, Statehood and the Law of Self-Determination (Kluwer, 2002), at 123

127 ibid.

128 SC Res. 541, 18 November 1983, para 6.

129 ibid. para 7.

130 See J. Crawford, The Creation of States in International law (OUP, 2006), at 144.

131 A. Pavkovic and P. Radan, Creating New States: Theory and Practice of Secession (Ashgate, 2007), at 102.

132 Crawford, supra note 130, at 140.

133 ibid. at 141.

134 ibid.
} 
accompli, which in the circumstances other States had no alternative but to accept.'135 However, under international law there was a problem; or rather, there should have been a problem. It is not contested that under the applicable Charter rules on the use of force, India's intervention was illegal. ${ }^{136}$ Consequently, the same should have happened as a decade later in Northern Cyprus - the intervention should have triggered the obligation to withhold recognition, now expressed in Article 41 of the ILC Articles of State Responsibility. Instead, Bangladesh had twenty-eight recognitions within weeks of declaring independence. ${ }^{137}$ In 1974, Pakistan recognised and recognition subsequently became universal. In the same year, Bangladesh was admitted to membership of the UN. ${ }^{138}$ It is notable that Bangladesh went through the voting procedure to be admitted to membership of the UN. This indicates that in this exceptional situation the international community as a whole was willing to accept the outcome of an illegal use of force.

Pakistan's recognition of Bangladesh was considered to be highly significant and may be seen as a waiver of its counterclaim to territorial integrity. But pursuant to Articles 26 and 41, the underlying illegality, that is, India's illegal use of force, could not be 'cured' or subsequently justified, not even by Pakistan's recognition. It is rather that the illegal use of force was seen as the choice of a lesser evil and the international community as a whole set aside observance of the obligation now reflected in Article 41 and, contrary to what is required by that article, recognised and aided assistance to a situation created in breach of a peremptory norm. ${ }^{139}$ It could also be arguable that the Turkish intervention in Cyprus or Russian intervention in Ukraine likewise 'produced a fait accompli, which in the circumstances other States [have] ...no alternative but to accept.' 140 Yet this was not the case. Contrasting these situations indicates that in situations other than Bangladesh the excuse was not persuasive enough.

\footnotetext{
135 ibid. at 393.

136 See T. Franck and N. Rodley, 'After Bangladesh: The Law of Humanitarian Intervention by Military Force', 67 AJ IL (1973) 275, 275- 76 and 290.

137 Crawford, supra note 130, at 141.

138 GA Res 3203 (XXIX), 17 September 1974.

139 cf Art. 41(2) ARSIWA.

140 Crawford, supra note 130 , at 393.
} 
Writing in 1973, Thomas Franck and Nigel Rodley noted:

In exceptional circumstances-and Bangladesh may turn out to be one of those rare cases-a large power may indeed go selflessly to the rescue of a foreign people facing oppression. But surely no general law is needed to cover such actions. All legal systems provide for mitigating circumstances. Yet, in human experience it has proven wiser to outlaw absolutely conduct which, in practical experience, is almost invariably harmful, rather than try to provide general exceptions for rare cases. ${ }^{141}$

This argument is comparable to Lowe's illustration with emergency drivers. ${ }^{142}$ It does not propose to undermine the rules on the use of force. It is rather an early plea for an excuse of an illegal use of force. The 1973 article by Franck and Rodley predates by almost three decades the final draft of the ILC Articles on State Responsibility. The Commentary to Article 41 of these Articles invokes situations where recognition upon illegal use of force was collectively withheld, ${ }^{143}$ but carefully avoids mentioning the counterexample of Bangladesh. This episode can thus be treated as an exception where a mitigating circumstance was accepted. As this article has shown, such circumstances can be accommodated within the framework of the secondary rules of state responsibility. And they should stay there.

\section{Conclusion}

The framework of the ILA Articles on State Responsibility conflates the concepts of justifications and excuses, and reveals that the distinction between primary and secondary rules of international law is not as rigid as is sometimes presented. This article proposes that international law should keep justifications and excuses separate. The circumstances precluding international wrongfulness invoke self-defence under Chapter VII, UN Charter, and consent of the injured state. Where force is used pursuant to Article 51, international wrongfulness is indeed precluded. Article 51 is a justification that operates on the level of primary norms. When engaged, force is used lawfully, there is no breach of a primary norm and, consequently, there is nothing the law of state

\footnotetext{
${ }^{141}$ Franck and Rodley, supra note 136, at 290 (emphasis in original).

$142 \mathrm{cf}$. supra note 5.

${ }^{143}$ ARSIWA with Commentaries, Commentary to Article 41.
} 
responsibility could regulate. The same applies for consent. Where intervention by invitation is at stake, consent of the inviting state precludes wrongfulness which would arise in the absence of invitation.

Excuses are different. There is no doubt or even denial that the primary norm was breached and international wrongfulness has occurred. But in the particular circumstances the wrongful behaviour was a matter of distress or necessity and was the choice of the lesser evil. This kind of reasoning underlies the aftermath of the 1999 intervention against the FRY when many prominent writers declared the use of force was 'illegal but legitimate'. Applying the concept of defences, 'illegal' means that it could not be justified under the applicable exceptions available under primary norms governing the use of force. 'Legitimate' means that it could be excused as being the choice of the lesser evil. The subsequent Resolution 1244 accepted the effective situation created by the illegal use of force, but did not provide for ex post justification. When Kosovo declared independence, the original illegality had not been justified, but it was nevertheless at least implicitly confirmed by the ICJ that the obligation to withhold recognition did not apply. In Bangladesh, the international community as a whole accepted the outcome of India's illegal but legitimate use of force as the lesser evil, and confirmed the emergence of a new state by both recognition and voting in favour of UN membership. In contrast, unjustified uses of force in Northern Cyprus and most recently Ukraine led to virtually universal withholdings of recognition and no mitigating circumstances were internationally accepted.

It thus follows that excuses of illegal, i.e. unjustified, uses of force have been accommodated within the secondary rules of state responsibility. This is despite the fact that the prohibition of illegal use of force is a peremptory norm. But peremptory norms in international legal doctrine and practice have a very narrow scope. Illegal use of force is a violation of jus cogens, but granting recognition to a situation created in its breach is not. This has no bearing for the primary norm on the use of force. This is an excuse, not a justification. In international law, excuses should operate exclusively on the level of secondary rules and mitigate against responsibility for a doubtless breach of a primary norm. If this distinction is established, excused breaches cannot be taken as state practice which can undermine or change the primary norm itself. While anticipatory self-defence is often used as an example of a customary justification to the 
prohibition of the use of force, this article proposes it should rather be seen as an excuse under the doctrine of necessity in the law of state responsibility. Given the primacy of the Charter in the post-1945 international legal order, it is indeed conceptually difficult to accept a customary justification for the use of force that would go beyond what is allowed by the Charter.

Practice of states and UN organs confirms that under limited circumstances an unlawful use of force will collectively be accepted as a matter of necessity and the choice of the lesser evil. Whether or not an unlawful use of force indeed was the lesser evil' can only be considered ex post. And an excuse does not 'cure' the original illegality; it can only lead to acceptance of the effective situation created by the breach. An excuse also leaves the primary norm intact. This is important, as it preserves the strength of the prohibition of the use of force and only mitigates against responsibility on the level of secondary rules.

The Charter reading needs to remain 'orthodox' in order to preserve the strength of the prohibition of the use of force. But the law of state responsibility can be, and has indeed been, more accommodating. 
NYU School of Law • New York, NY 10011 